\begin{tabular}{c|l|l|l}
$\begin{array}{c}\text { Case Reports in } \\
\text { Oncology }\end{array}$ & $\begin{array}{l}\text { Case Rep Oncol 2010;3:463-470 } \\
\text { DOI: 10.1159/000323152 }\end{array}$ & $\begin{array}{l}\text { Published online: } \\
\text { December 11, 2010 }\end{array}$ & $\begin{array}{l}\text { O 2010 S. Karger AG, Basel } \\
\text { ISSN 1662-6575 } \\
\text { www.karger.com/cro }\end{array}$ \\
\hline
\end{tabular}

\title{
A Case Report of a Patient with Hereditary Hemorrhagic Telangiectasia Treated Successively with Thalidomide and Bevacizumab
}

\author{
Ahmad Amanzada Gwen-Jana Töppler Silke Cameron \\ Harald Schwörer Giuliano Ramadori \\ Department of Gastroenterology and Endocrinology, University Clinic of the \\ Georg August University, Göttingen, Germany
}

\section{Key Words}

Hereditary hemorrhagic telangiectasia $\cdot$ Thalidomide $\cdot$ Bevacizumab

\begin{abstract}
Hereditary hemorrhagic telangiectasia is characterized by mucocutaneous and visceral telangiectasia and involves several organs with vascular malformations. It is an autosomal dominant disease and is distinguished into three types, which are due to mutations in different genes. The common symptom is anemia, causing a continous need of blood transfusion. Depending on the severity and disease manifestation, there are various forms of therapy ranging from local therapy activities to operations or drug therapy. Here we describe a dramatic improvement of a patient with a high transfusion frequency due to severe recurrent anemia successively treated with thalidomide and bevacizumab.
\end{abstract}

\section{Introduction}

Hereditary hemorrhagic telangiectasia (HHT) or Osler-Weber-Rendu syndrome is inherited as an autosomal dominant trait, and has a general prevalence of $1 / 10,000$ in Caucasians and a prevalence as high as 1/400 in Dutch Antillean people [1]. HHT is characterized by widespread telangiectases that can involve the skin, mucous membranes, lung, brain, the gastrointestinal tract and/or liver [2]. The telangiectasia is the characteristic lesion of HHT. It arises from a dilated post capillary venule that enlarges and fuses with an arteriole bypassing the capillary system and resulting in an arteriovenous communication [1]. It can present as discrete arteriovenous malformations (AVMs) or as multiple diffuse telangiectases. 
The clinical diagnosis of HHT is based on the presence of at least three of four main clinical features: epistaxis, cutaneous or mucosal telangiectases, visceral involvement and a family history of HHT [3]. AVMs also occur in internal organs, especially in the lungs (in about 33\% of patients), in the gastrointestinal tract (in about 44\%) and in the liver (in around $17 \%$ ). Up to $15 \%$ of the patients are also diagnosed with cerebral involvement [46]. Through the pulmonary AVM, the filtering effect of the pulmonary capillaries is restricted. Bacteria and clots can pass through the lungs and subsequently lead to cerebral abscesses and emboli. Gastrointestinal bleeding usually begins in the fifth decade of life, makes frequent blood transfusions necessary and may in some cases even lead to the death of the patient [7]. The liver is commonly affected by vascular malformations that may produce portovenous (portal vein to hepatic vein), arteriovenous (hepatic artery to hepatic vein), and arterioportal (hepatic artery to portal vein) shunting [2]. Although hepatic involvement is often asymptomatic, the commonest clinical manifestation is highoutput cardiac failure secondary to intrahepatic shunting leading to breathlessness and fluid retention. Ascites and variceal bleeding are presented as a result of portal hypertension by arterioportal shunting, whereas arteriovenous shunting can cause biliary ischemia with subsequent necrosis and sclerosing cholangitis [8]. Cerebral and spinal malformations may present with seizures, hemorrhage, headaches and neurological deficits [9].

HHT is caused by mutations in one of two genes that have led to its subclassification into types 1 and 2. Type $2 \mathrm{HHT}$ is more frequent. Both genes encode for transmembrane proteins involved in the transforming growth factor (TGF) $\beta$ signalling pathway and are expressed predominantly on vascular endothelium [2]. For HHT type 1, a mutation in the endoglin gene on chromosome 9q34 is responsible [10] and for HHT type 2 a mutation in the gene for the activin receptor-like kinase 1 (ALK-1) on chromosome 12q13 [11]. Additionally, a HHT type 3 has been described in a family with HHT and pulmonary involvement due to endoglin, ALK-1 and Smad4 mutations. In this family, a previously unidentified disease gene was identified on chromosome 5 [12].

Sadick et al. [13] showed increased plasma levels of vascular endothelial growth factor and TGF- $\beta$ in patients with HHT. Thalidomide, originally used to treat nausea in pregnancy in the early 1960s, was removed from the market when severe congenital defects became evident in newborns, a result of its antiangiogenic activity that reduced the blood supply to fetal organs and tissues at specific times of development $[14,15]$. However, thalidomide has enjoyed a renaissance in recent years. Under strict guidelines and carefully controlled inclusion criteria, it is now used to treat various pathologies: it reportedly inhibits bleeding in individuals with certain gastrointestinal diseases [16-19] and in HHT patients who received thalidomide as an antiangiogenic cancer therapy [20, 21]. The mechanisms by which thalidomide inhibits bleeding from vascular malformations are unknown, although it has been reported to regulate the expression of components of signaling pathways that are involved in stimulating or inhibiting angiogenesis, such as the VEGF pathway [22]. More recently, it has been shown to target endothelial tip cells of immature vessels [15].

Several case reports have been published on HHT patients who were treated with bevacizumab only [23-27]. We present a case of a patient with severe HHT first treated with thalidomide and subsequently with bevacizumab. 


\begin{tabular}{|c|c|c|c|}
\hline $\begin{array}{c}\text { Case Reports in } \\
\text { Oncoloys }\end{array}$ & \begin{tabular}{|l|} 
Case Rep Oncol 2010;3:463-470 \\
DOI: $10.1159 / 000323152$
\end{tabular} & $\begin{array}{l}\text { Published online: } \\
\text { December } 11,2010\end{array}$ & $\begin{array}{l}\text { O 2010 S. Karger AG, Basel } \\
\text { ISSN 1662-6575 } \\
\text { www.karger.com/cro }\end{array}$ \\
\hline
\end{tabular}

\section{Case Report}

A 59-year-old man with a history of HHT for 20 years first presented to our hospital in 1998 (fig. 1). He had been smoking for several years and had developed a chronic obstructive pulmonary disease. He had taken tiotropium bromide and beclometasone dipropionate as a dose inhaler for some years. Iron substitution had been performed for several years. Multiple angiodysplasias of the gastrointestinal tract were diagnosed by endoscopic investigations. These angiodysplasias were localised primarily in the corpus ventriculi, duodenum and jejunum (fig. 2). Several endoscopic interventions were performed, such as argon beamer coagulation. But the frequency of required blood transfusions was not reduced significantly by these interventions. In February 2005, an AVM in the right lower lung was discovered. A right heart catheter investigation measured a shunt flow of $16 \%$ of the cardiac output. In the same session, the shunt was occluded. Hypothyroidism was diagnosed in 2007. Since then the patient had been treated with thyroxine. Starting from 2004, the patient developed multiple antibodies and cold agglutinins. Therefore, the procurement of appropriate erythrocyte concentrates is very difficult. To achieve a reduction of the transfusion frequency, we first started a thalidomide therapy ( $200 \mathrm{mg} /$ day $)$ in March 2005. As fig. 3 and fig. 4 show, the frequency of transfusions could be reduced markedly under thalidomide therapy. This therapy was continued until August 2007, when it had to be discontinued because of deterioration of lung function. After termination of the thalidomide therapy, a slight increase of the frequency of required transfusions was noticeable. Therefore, in May 2008, we decided to begin a therapy with the monoclonal human antibody bevacizumab (fig. 3, 4). From the start of therapy with bevacizumab until June 2010, the patient needed only 43 erythrocyte concentrates. Under thalidomide therapy, 183 had been necessary and before these two therapies the patient had received 700 erythrocyte concentrates from April 1998 to March 2005 (fig. 3).

Starting from April 1998, the patient has received erythrocyte concentrates in our clinic only. Since then he has received a total of 958 erythrocytes concentrates. Before 1998 we cannot specify the number of received erythrocyte concentrates, because he had been treated in various hospitals.

The serology for hepatitis B, C and human immunodeficiency virus is fortunately negative.

\section{Discussion}

Patients with HHT had so far been treated only with blood transfusions. In patients with epistaxis, multiple approaches have been tried, including electrocautery, laser, septodermoplasty, embolization, arterial ligation, and, most recently, sprayable fibrin sealant $[28,29]$. All of these approaches are largely palliative with variable results, many requiring repeated interventions, except for nasal closure [30].

In HHT patients with gastrointestinal bleeding, numerous endoscopic examinations or surgical resections are performed to prevent recurrent bleeding. However, these are also palliative approaches. In addition, these patients must receive erythrocyte concentrates and iron substitution. Gastrointestinal bleeding in HHT patients could be reduced by administration of an estrogen-progesterone combination [31]. This therapy has the advantage that the gastrointestinal sections are treated, which cannot be examined endoscopically. In a study by van Cutsem et al. [32] in several HHT patients with gastrointestinal bleeding the number of required blood transfusions could be reduced after hormone treatment. This therapy, however, is problematic for male patients because the side effects (such as gynecomastia, edema, and feminization) are often very pronounced. Therefore, the hormone therapy is actually reserved to postmenopausal women who have undergone hysterectomy.

In recent years, the process of catheter embolization for pulmonary AVMs has been enforced. The enlarged vessels are closed using coils, sometimes supplemented by small 


\begin{tabular}{c|l|l|l}
$\begin{array}{c}\text { Case Reports in } \\
\text { Oncology }\end{array}$ & $\begin{array}{l}\text { Case Rep Oncol 2010;3:463-470 } \\
\text { DOI: 10.1159/000323152 }\end{array}$ & $\begin{array}{l}\text { Published online: } \\
\text { December 11, 2010 }\end{array}$ & $\begin{array}{l}\text { O 2010 S. Karger AG, Basel } \\
\text { ISSN 1662-6575 } \\
\text { www.karger.com/cro }\end{array}$ \\
\hline
\end{tabular}

balloons. Despite the success of this treatment, remaining AVMs are diagnosed in up to $60 \%$ of the patients [33].

Currently, treatment of patients with hepatic HHT with liver transplantation is curative but involves a risk of acute mortality as well as problems of long-term immunosuppression. Hepatic arterial embolization or occlusion is associated with significant morbidity and mortality and is not recommended outside palliative circumstances $[2,34]$. Recommendations for therapy of cerebral AVMs are not available.

Our patient was treated for recurrent anemia with transfusions until March 2005. The thalidomide therapy halved the number of transfusions. As after thalidomide therapy the frequency of blood transfusion units increased, a therapy with bevacizumab was started. The therapy with bevacizumab caused a dramatic reduction of the number of required transfusions. In these two years, only 43 erythrocyte concentrates were administered.

Impressive as these data may be, one must also be careful because bevacizumab has also a nonnegligible toxicity. In fact, it may induce cardiac failure, hemorrhage, arterial thromboembolic events, hypertensive crisis, nephritic syndrome and wound-healing.

Although multiple drugs have been evaluated, there is currently no randomized controlled trial confirming efficacy for preventing bleeding from vascular malformations. Therefore, an effective medical treatment for these patients is urgently needed. A clinical trail with bevacizumab for patients with severe HHT is warranted. 


\begin{tabular}{c|l|l|l}
$\begin{array}{c}\text { Case Reports in } \\
\text { Oncology }\end{array}$ & $\begin{array}{l}\text { Case Rep Oncol 2010;3:463-470 } \\
\text { DOI: 10.1159/000323152 }\end{array}$ & $\begin{array}{l}\text { Published online: } \\
\text { December 11, 2010 }\end{array}$ & $\begin{array}{l}\text { O 2010 S. Karger AG, Basel } \\
\text { ISSN 1662-6575 } \\
\text { www.karger.com/cro }\end{array}$ \\
\hline
\end{tabular}

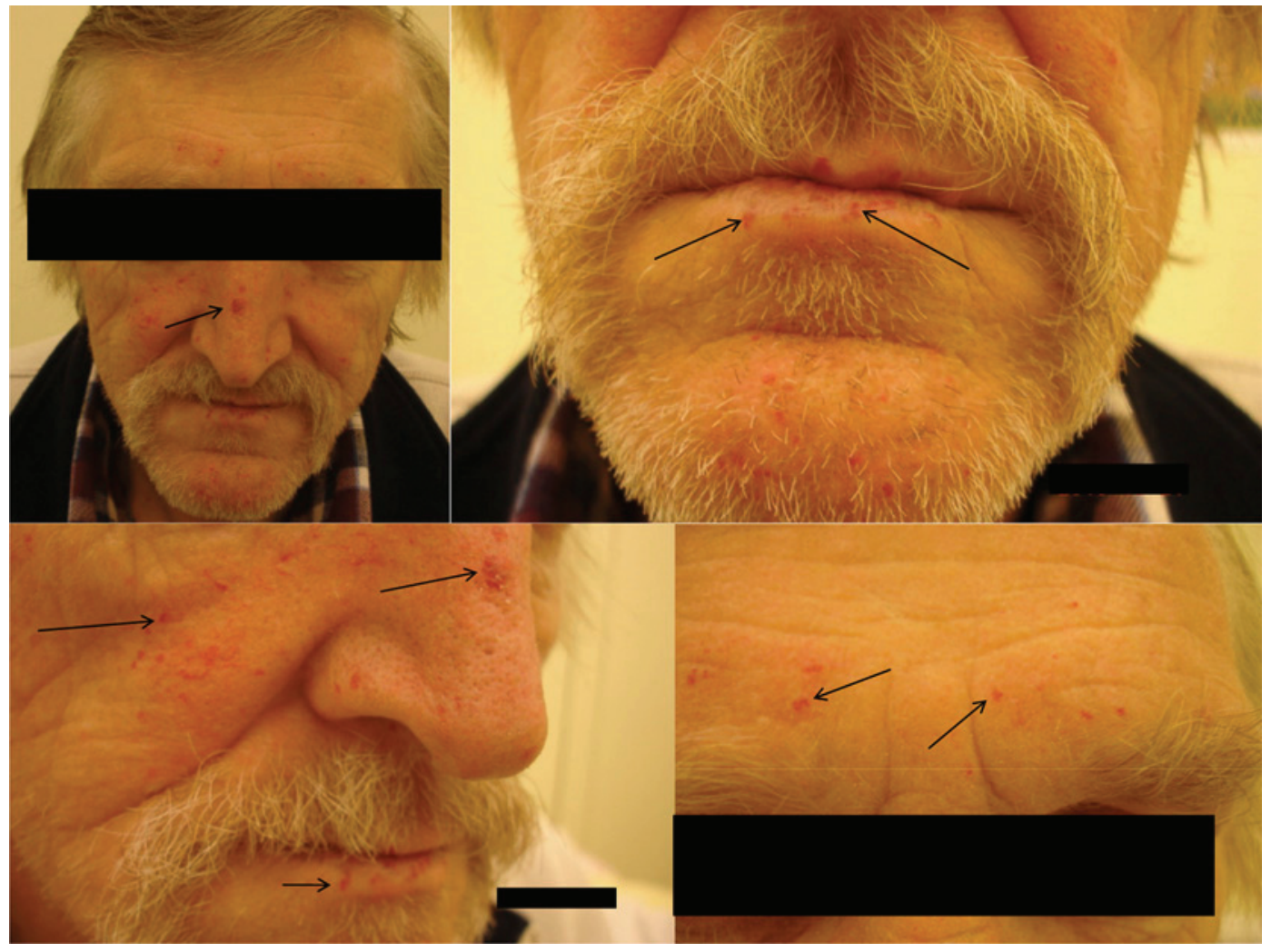

Fig. 1. Images of the patient with multiple HHT of the skin. 


\begin{tabular}{|c|c|c|c|}
\hline $\begin{array}{l}\text { Case Reports in } \\
\text { Oncoloy }\end{array}$ & $\begin{array}{l}\text { Case Rep Oncol 2010;3:463-470 } \\
\text { DOI: } 10.1159 / 000323152\end{array}$ & $\begin{array}{l}\text { Published online: } \\
\text { December 11, } 2010\end{array}$ & $\begin{array}{l}\text { ( ) } 2010 \text { S. Karger AG, Basel } \\
\text { ISSN } 1662-6575 \\
\text { www.karger.com/cro }\end{array}$ \\
\hline
\end{tabular}
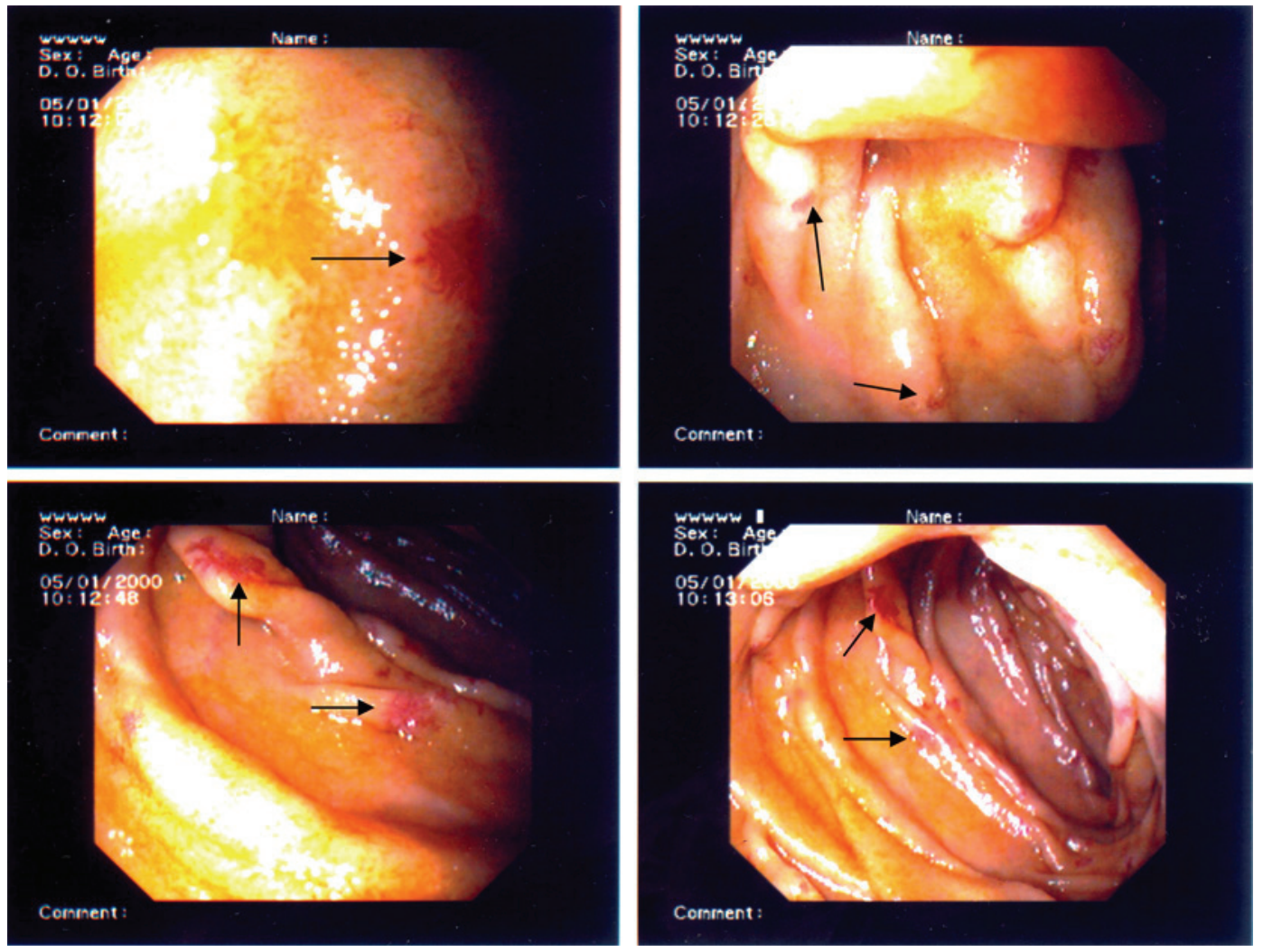

Fig. 2. Enteroscopy image of the patient. These images show the jejunum at $150 \mathrm{~cm}$ aboral. There are multiple angiodysplasias (arrows) without macroscopically visible bleeding.

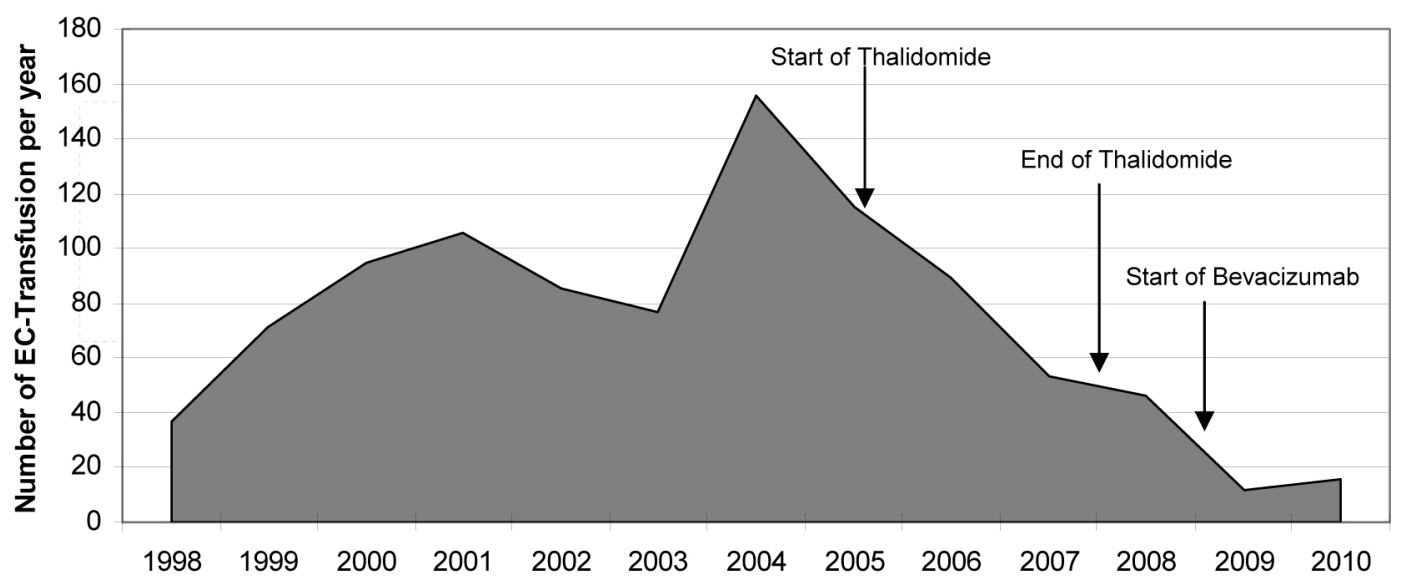

Fig. 3. The number of erythrocyte concentrate (EC) transfusions per year from April 1998 till June 2010. 


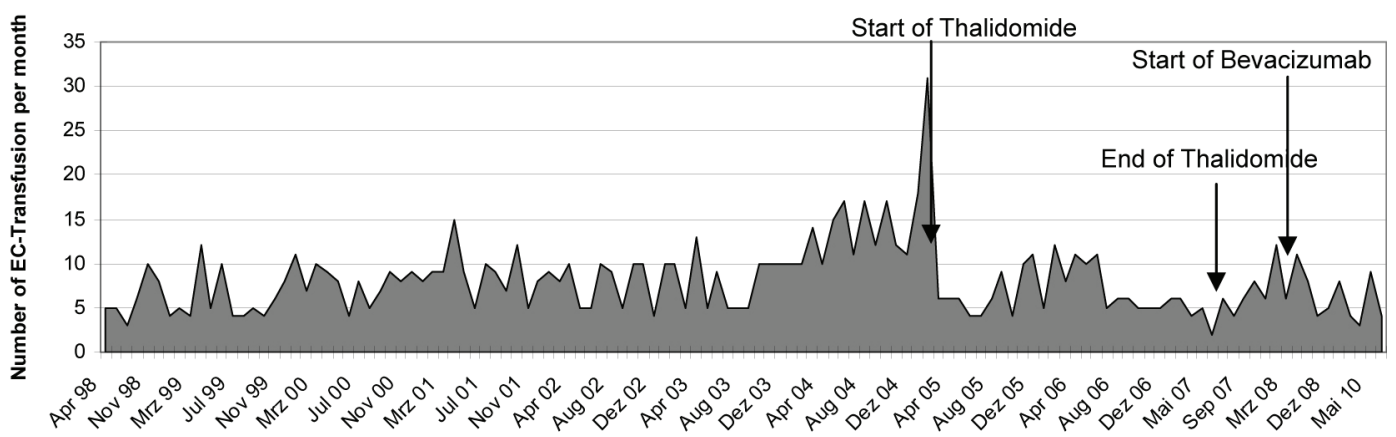

Fig. 4. The number of erythrocyte concentrate (EC) transfusions per month from April 1998 till June 2010 .

\section{References}

1 Guttmacher AE, Marchuk DA, White RI Jr: Hereditary hemorrhagic telangiectasia. N Engl J Med 1995;333:918-924.

2 Garcia-Tsao G: Liver involvement in hereditary hemorrhagic telangiectasia. J Hepatol 2007;46:499-507.

-3 Shovlin CL, Guttmacher AE, Buscarini E, Faughnan ME, Hyland RH, Westermann CJ, Kjeldsen AD, Plauchu $\mathrm{H}$ : Diagnostic criteria for hereditary hemorrhagic telangiectasia (Rendu-Osler-Weber syndrome). Am J Med Genet. 2000;91:66-67.

4 Haitjema T, Westermann CJJ, Overtoom TTC, Timmer R, Disch F, et al: Hereditary hemorrhagic teleangiectasia (Osler-Weber-Rendu-disease): new insights in pathogenesis, complications, and treatment. Arch Intern Med 1996;156:714-719.

-5 Reilly PJ, Nostrant TT: Clinical manifestations of hereditary hemorrhagic telangiectasia. Am J Gastroenterol 1984;79:363-367.

-6 McDonald JE, Miller FJ, Hallam SE, Nelson L, Marchuk DA, Ward KJ: Clinical manifestations in a large hereditary hemorrhagic telangiectasia (HHT) type 2 kindred. Am J Med Genet 2000;93:320-327.

-7 Plauchu H, de Chadarevian JP, Bideau A, Robert JM: Age-related clinical profile of hereditary hemorrhagic telangiectasia in an epidemiologically recruited population. Am J Med Genet 1989;32:291-297.

-8 Garcia-Tsao G, Korzenik JR, Young L, Henderson KJ, Jain D, et al: Liver disease in patients with hereditary hemorrhagic telangiectasia. N Engl J Med 2000;343:931-936.

-9 Matsubara S, Mandzia JL, ter Brugge K, Willinsky RA, Faughnan ME: Angiographic and clinical characteristics of patients with cerebral arteriovenous malformations associated with hereditary hemorrhagic telangiectasia. AJNR Am J Neuroradiol 2000;21:1016-1020.

10 McAllister KA, Grogg KM, Johnson DW, et al: Endoglin, a TGF-beta binding protein of endothelial cells, is the gene for hereditary haemorrhagic telangiectasia type 1. Nat Genet 1994;8:345-351.

11 Johnson DW, Berg JN, Baldwin MA, et al: Mutations in the activin receptor-like kinase 1 gene in hereditary haemorrhagic telangiectasia type 2. Nat Genet 1996;13:189-195.

12 Cole SG, Begbie ME, Wallace GM, Shovlin CL: A new locus for hereditary haemorrhagic telangiectasia (HHT3) maps to chromosome 5. J Med Genet 2005;42:577-582.

13 Sadick H, Riedel F, Naim R, Goessler U, Hörmann K, Hafner M, Lux A: Patients with hereditary hemorrhagic telangiectasia have increased plasma levels of vascular endothelial growth factor and transforming growth factor-beta 1 as well as high ALK1 tissue expression. Haematologica 2005;90:818-828.

14 D'Amato RJ, Loughnan MS, Flynn E, Folkman J: Thalidomide is an inhibitor of angiogenesis. Proc Natl Acad Sci 1994;91:4082-4085.

15 Therapontos C, Erskine L, Gardner ER, Figg WD, Vargesson N: Thalidomide induces limb defects by preventing angiogenic outgrowth during early limb formation. Proc Natl Acad Sci 2009;106:8573-8578.

16 Bauditz J, Lochs H: Angiogenesis and vascular malformations: antiangiogenic drugs for treatment of gastrointestinal bleeding. World J Gastroenterol 2007;13:5979-5984.

17 Bauditz J, Schachschal G, Wedel S, Lochs H: Thalidomide for treatment of severe intestinal bleeding. Gut 2004;53:609-612. 
18 Dabak V, Kuriakose P, Kamboj G, Shurafa M: A pilot study of thalidomide in recurrent GI bleeding due to angiodysplasias. Dig Dis Sci 2008;53:1632-1635.

19 Kamalaporn P, et al: Thalidomide for the treatment of chronic gastrointestinal bleeding from angiodysplasias: a case series. Eur J Gastroenterol Hepatol 2009;21:1347-1350.

20 Kurstin R: Using thalidomide in a patient with epithelioid leiomyosarcoma and Osler-Weber-Rendu disease. Oncology 2002;16:21-24.

21 Pérez-Encinas M, Rabunal Martinez MJ, Bello Lopez JL: Is thalidomide effective for the treatment of gastrointestinal bleeding in hereditary hemorrhagic telangiectasia? Haematologica 2002;87:ELT34.

-22 Melchert M, List A: The thalidomide saga. Int J Biochem Cell Biol 2007;39:1489-1499.

23 Flieger D, Hainke S, Fischbach W: Dramatic improvement in hereditary hemorrhagic telangiectasia after treatment with the vascular endothelial growth factor (VEGF) antagonist bevacizumab. Ann Hematol 2006;85:631-632.

-24 Bose P, Holter JL, Selby GB: Bevacizumab in hereditary hemorrhagic telangiectasia. N Engl J Med 2009;360:2143-2144.

-25 Oosting S, Nagengast W, de Vries E: More on bevacizumab in hereditary hemorrhagic telangiectasia. N Engl J Med 2009;361:931.

-26 Davidson TM, Olitsky SE, Wei LL: Hereditary hemorrhagic telangiectasia/avastin. Laryngoscope 2010;120:432-435.

27 Mitchell A, Adams LA, MacQuillan G, Tibballs J, vanden Driesen R, Delriviere L: Bevacizumab reverses need for liver transplantation in hereditary hemorrhagic telangiectasia. Liver Transpl 2008;14:210-213.

-28 Richmon JD, Tian Y, Husseman J, Davidson TM: Use of a sprayed fibrin hemostatic sealant after laser therapy for hereditary hemorrhagic telangiectasia epistaxis. Am J Rhinol 2007;21:187-191.

29 Harvey RJ, Kanagalingam J, Lund VJ: The impact of septodermoplasty and potassium-titanyl-phosphate (KTP) laser therapy in the treatment of hereditary hemorrhagic telangiectasia-related epistaxis. Am J Rhinol 2008;22:182-187.

30 Lund VJ, Howard DJ: Closure of the nasal cavities in the treatment of refractory hereditary haemorrhagic telangiectasia. J Laryngol Otol 1997;111:30-33.

- 31 Flessa HC, Glueck HI: Hereditary hemorrhagic telangiectasia (Osler-Weber-Rendu disease): management of epistaxis in nine patients using systemic hormone therapy. Arch Otolaryngol 1977;103:148-151.

- 32 van Cutsem E, Rutgeerts P, Vantrappen G: Treatment of bleeding gastrointestinal vascular malformations with oestrogen-progesterone. Lancet 1990;335:953-955.

-33 Shovlin CL, Letarte M: Hereditary haemorrhagic telangiectasia and pulmonary arteriovenous malformations: issues in clinical management and review of pathogenic mechanisms. Thorax 1999;54:714-729.

-34 Lerut J, Orlando G, Adam R, Sabbà C, Pfitzmann R, Klempnauer J, et al: Liver transplantation for hereditary hemorrhagic telangiectasia: report of the European liver transplant registry. Ann Surg 2006;244:854-864. 